\title{
Serological and molecular investigation of Leishmania spp. infection in cats from an area endemic for canine and human leishmaniasis in Northeast Brazil
}

Investigação sorológica e molecular da infecção por Leishmania spp. em gatos provenientes de uma área endêmica para leishmaniose canina e humana no nordeste brasileiro

José Artur Brilhante Bezerra ${ }^{1}$; Ilanna Vanessa Pristo de Medeiros Oliveira ${ }^{1}$; Ana Carolina Yamakawa ${ }^{2}$;

Mariana Guimarães Nilsson ${ }^{2}$; Klívio Loreno Raulino Tomaz ${ }^{1}$; Kalyne Danielly Silva de Oliveira ${ }^{1}$;

Célio Souza da Rocha ${ }^{1}$; Cecília Irene Perez Calabuig ${ }^{1}$; Felipe Fornazari ${ }^{2}$; Helio Langoni²;

João Marcelo Azevedo de Paula Antunes ${ }^{1 *}$ (b)

\begin{abstract}
${ }^{1}$ Hospital Veterinário Jerônimo Dix-Huit Rosado Maia, Universidade Federal Rural do Semi-Árido - UFERSA, Mossoró, RN, Brasil
${ }^{2}$ Núcleo de Pesquisas em Zoonoses - NUPEZO, Departamento de Higiene Veterinária e Saúde Pública, Faculdade de Medicina

Veterinária e Zootecnia, Universidade Estadual Paulista - UNESP, Botucatu, SP, Brasil
\end{abstract}

Received May 02, 2019

Accepted August 12, 2019

\begin{abstract}
The aim of this study was to investigate the occurrence of Leishmania spp. antibodies, and its association with feline immunodeficiency virus (FIV) and feline leukemia virus (FeLV), in domestic cats from an area endemic for canine and human leishmaniasis in Rio Grande do Norte State, Brazil. Ninety-one cats were subjected to a complete clinical exam, and blood samples were collected. An epidemiological questionnaire was used to investigate the risk factors. IgG anti-Leishmania spp. antibodies were detected by immunofluorescence antibody test (IFAT), with a cut-off value of 1:40. Polymerase chain reaction (PCR) was performed to detect genetic material of Leishmania spp. in the blood samples. The presence of antibodies against FIV and antigens of FeLV was evaluated using an immunochromatographic test. Seropositivity for Leishmania spp., FIV, and FeLV was observed in 14/91 (15.38\%), 26/91 (28.57\%), and $3 / 91$ (3.29\%) cats, respectively. All samples gave negative results on PCR analysis. Based on these data, no significant statistical association was observed between seropositivity for Leishmania spp., and sex, age, presence of clinical signs, evaluated risk factors, and positivity for retroviruses. These findings demonstrated for the first time that cats from Mossoró, Rio Grande do Norte, are being exposed to this zoonosis and might be part of the epidemiological chain of transmission of visceral leishmaniasis.
\end{abstract}

Keywords: Leishmaniasis, Felis catus, zoonosis, epidemiology, IFAT.

\section{Resumo}

O objetivo do presente estudo foi investigar a ocorrência de anticorpos contra Leishmania spp., e sua associação com o vírus da imunodeficiência felina (FIV) e o vírus da leucemia felina (FeLV), em felinos domésticos provenientes de uma área endêmica no estado do Rio Grande do Norte, para a leishmaniose visceral canina e humana. Noventa e um gatos foram submetidos a exame clínico completo e amostras de sangue foram coletadas. Um questionário epidemiológico foi feito para investigar fatores de risco. Anticorpos IgG anti-Leishmania spp. foram identificados por meio da imunofluorescência indireta (RIFI), adotando-se como ponto de corte a diluição de 1:40. A reação em cadeia da polimerase (PCR) foi executada visando detectar o material genético de Leishmania spp. a partir de amostras de sangue total. Para avaliar a presença de anticorpos contra o FIV e antígenos do FeLV foi utilizado um teste imunocromatográfico. Observou-se soropositividade em 14/91 (15,38\%), 26/91 (28,57\%) e 3/91 (3,29\%) animais para Leishmania spp., FIV e FeLV, respectivamente. Nenhuma amostra foi positiva na PCR. Baseado nestes dados, não foi observada nenhuma associação estatística significativa entre a soropositividade para Leishmania spp. e gênero, idade, presença de sinais clínicos, fatores 
de risco avaliados e positividade para as retroviroses. Esses achados demonstram pela primeira vez que felinos da cidade Mossoró, Rio Grande do Norte, estão sendo expostos a esta zoonose, sugerindo que os mesmos podem estar participando da cadeia epidemiológica de transmissão da leishmaniose visceral.

Palavras-chave: Leishmaniose, Felis catus, zoonose, epidemiologia, RIFI.

Feline leishmaniasis (FeL), which is mainly caused by Leishmania infantum, is considered to be an emerging disease (PENNISI \& PERSICHETTI, 2018). In the last two decades, there has been a considerable increase in epidemiological studies and reports of FeL, especially in areas endemic for canine and human leishmaniasis (PENNISI et al., 2015). However, there is limited knowledge about its immunological and pathophysiological aspects, making the diagnosis challenging (SILVEIRA et al., 2015).

FeL has some particularities compared to dogs. Cats are considered to be more resistant to Leishmania infection, remaining asymptomatic, with parasitemia, even 16 weeks after L. infantum inoculation at a dose that usually results in clinical disease in dogs (AKHTARDANESH et al., 2018). Experimentally infected cats are capable of transmitting the protozoan to sand flies (MAROLI et al., 2007; SILVA et al., 2010). Nevertheless, studies are not consistent in affirming the precise role of cats in the epidemiology of this disease under natural conditions (PENNISI \& PERSICHETTI, 2018).

Some authors have hypothesized that feline retroviruses, the feline immunodeficiency virus (FIV) and the feline leukemia virus (FeLV), are predisposing factors for FeL in endemic areas, due to its immunosuppressant characteristics, but only a few studies found a significant association between these infections (PENNISI et al., 1998; AYLLÓN et al., 2012; SOBRINHO et al., 2012; SPADA et al., 2013).

In Brazil, studies on FeL using serological, parasitological, and molecular methods revealed that infection frequencies varied from 0\% to 54\% (BRESCIANI et al., 2010; VIDES et al., 2011; CARDIA et al., 2013; BRAGA et al., 2014; SILVA et al., 2014; SOUSA et al., 2014; OLIVEIRA et al., 2015; GODOI et al., 2016; MENDONÇA et al., 2017; COURA et al., 2018; MATOS et al., 2018). Only a small fraction of these studies was performed in the Northeast region that was home to $82.5 \%$ of all reported cases of human leishmaniasis in Brazil between 1980 and 2005, making this region an area of epidemiological relevance for this disease in Brazil (MAIA-ELKHOURY et al., 2008; SILVA et al., 2014; MENDONÇA et al., 2017). Because of the high prevalence of leishmaniasis in Northeast Brazil and due to the lack of scientific data about FeL in Rio Grande do Norte State, the aim of this study was to investigate Leishmania spp. infection using serological and molecular methods, and its association with FIV and FeLV, in domestic cats in Mossoró city - a region that is endemic for human and canine leishmaniasis.

The study was performed from August 2017 to September 2018. The Ethics Committee on Animals' Use (CEUA) of the Universidade Federal Rural do Semi-Árido (UFERSA) approved the experimental protocols and the procedures used for animal care (Process n ${ }^{\circ}$ 23091.008147/2017-28).

Cats older than 6 months in age $(n=91)$ treated at Hospital Veterinário Jerônimo Dix-Huit Rosado Maia from UFERSA were selected (Mossoró, RN, Brazil, 5¹00'S, 3700’W) for this study. The cats were clinically examined, and data related to each animal and its clinical status were noted. Blood samples ( $5 \mathrm{~mL}$ ) were collected by jugular venipuncture. Whole blood and serum samples were stored at $-20^{\circ} \mathrm{C}$ prior to performing serological and molecular tests at the Núcleo de Pesquisas em Zoonoses (NUPEZO), Departamento de Higiene Veterinária e Saúde Pública da Faculdade de Medicina Veterinária e Zootecnia da UNESP, Campus of Botucatu, SP, Brazil.

Epidemiological questionnaires were used to identify risk factors related to Leishmania infection. The variables analyzed and the respective categories were as follows: sex, age (young, older than 6 months, but lesser than 1 year in age; adult, older than 1 year, but lesser than 8 years in age; senior, older than 8 years), access to streets (yes or no), contact with dogs (yes or no), living near water sources (yes or no), health status (healthy or sick), vaccination (yes or no), deworming (yes or no), and castration (yes or no). Specific clinical signs were selected to evaluate the association with FeL_cutaneous signs, lymphadenomegaly, ophthalmic signs, gingivostomatitis, weight loss, and pale mucosa.

IgG anti-FIV antibodies and p27 FeLV antigens were investigated using a rapid immunochromatographic test (Alere S.A., São Paulo, SP, Brazil). The test was performed as per manufacturers' recommendations, using serum samples.

IgG anti-Leishmania spp. antibodies were detected by immunofluorescence antibody test (IFAT), according to the method described by Camargo (1974). Immunofluorescence slides were sensitized with Leishmania major promastigotes obtained from cultures maintained in liver infusion tryptose (LIT) and Neal, Novy, Nicolle (NNN) media. Positive and negative controls were used for all slides. Serial serum dilutions of $1: 40,1: 80,1: 160,1: 320$, and 1:640 were prepared in phosphate buffered saline (PBS, pH 7.2), and a dilution of 1:40 was adopted as the cut-off value. A commercial anti-IgG antibody specific to cats, conjugated with the fluorescein isothiocyanate (Sigma-Aldrich, St. Louis, MO, USA), was used as a secondary antibody. Slides were examined using a fluorescence microscope at magnification of $40 \times$ (Scope.A1; ZEISS, Oberkochen, Germany). After checking the control slides, the highest dilution of the serum for which complete fluorescence occurred at the border of at least $50 \%$ of the promastigotes was considered.

DNA extraction from blood samples was performed using Illustra $^{\mathrm{Tm}}$ blood GenomicPrep Mini Spin kit (GE Healthcare, Chicago, IL, USA), following manufacturers' recommendations. Extracted samples were stored in DNAse- and RNAse-free micro tubes at $-20^{\circ} \mathrm{C}$ prior to PCR. DNA samples were quantified in a spectrophotometer (NanoVue Plus; GE Healthcare, Chicago, IL, USA).

Primers 150, 5'-GGG(G/T)AGGGGCGTTCT(C/G) CGAA-3', and 152, 5'-(C/G)(C/G)(C/G)(A/T)CTAT(A/T) TTACACCAACCCC-3', were used as described by Volpini et al. (2004). All reactions were performed using Go Taq ${ }^{\circledR}$ Green Master 
Mix (Promega Corporation, Madison, WI, USA), a premixed solution containing Taq DNA polymerase, dNTPs, $\mathrm{MgCl}_{2}$ and reaction buffers, following manufacturers' recommendations. For each reaction was used a total of $12.5 \mu \mathrm{L}$ of $\mathrm{GoTaq}^{\circledR}$ Green Master Mix, $1 \mu \mathrm{L}$ of each primer, $7.5 \mu \mathrm{L}$ of nuclease-free water and $3 \mu \mathrm{L}$ of the extracted samples, obtained a total volume of $25 \mu \mathrm{L}$. DNA sample extracted from L. major (MHOM/SU/1973/5-ASKH strain) was used as a positive control. Ultrapure DNAse/RNAse-Free distilled water was used as a negative control.

The amplification steps were carried out in a thermal cycler (Mastercycler pro; Eppendorf, Hamburg, Germany) as follows: initial denaturation at $95^{\circ} \mathrm{C}$ for $5 \mathrm{~min}$, followed by 29 cycles at $95^{\circ} \mathrm{C}$ for $1 \mathrm{~min}, 55^{\circ} \mathrm{C}$ for $30 \mathrm{~s}$, and $72^{\circ} \mathrm{C}$ for $10 \mathrm{~s}$, and final extension of $72^{\circ} \mathrm{C}$ for $5 \mathrm{~min}$. Electrophoresis was performed in a $2 \%$ agarose gel stained with Nancy-520 ${ }^{\circledR}$ (Sigma-Aldrich, St. Louis, MO, USA) in $1 x$ TBE buffer, at 80 Volts (V) for 20 min followed by $100 \mathrm{~V}$ for 20 min, with DNA MW Marker 100-bp Ladder ${ }^{\circledR}$ (Sinapse Biotecnologia, Tatuapé, SP, Brazil). The result was visualized at an ultraviolet transilluminator. The amplified products had an expected molecular weight of $120 \mathrm{bp}$; this corresponded to the molecular weight of the Leishmania minicircle kinetoplast DNA (kDNA).

For statistical analysis, contingence tables were prepared to identify the differences in infected animal proportions with respect to each variable assessed. Chi-square test was used to compare proportion of infected animals with respect to the risk factors, using a significance value of $p<0.05$. To perform these analyses, the software IBM SPSS Statistics Version 22 was used.

Of the 91 cats studied, 51 (56\%) were male, and 40 (44\%) were female. All animals were crossbred. Using IFAT, IgG anti-Leishmania spp. antibodies were observed in 14 (15.38\%), with titers varying from 1:40 to 1:320 (Table 1 and Table 2). None of the cats were found to be positive for Leishmania infection using blood PCR. With respect to retrovirus infection, 26 (28.57\%) cats tested positive for FIV and 3 (3.29\%) cats tested positive for FeLV.

No statistical association was observed between seropositivity for Leishmania spp., and sex, age, presence of specific clinical signs, and evaluated risk factors. An association with retroviral infection was not observed, and only five cats had coinfection of Leishmania spp. and FIV ( $p=0.052)$. Of these coinfected animals, two presented a titer of 1:40, two had a titer of 1:80, and one had titer of 1:160. Clinical data for cats seropositive for Leishmania spp. are shown in Table 1, Figure 1, and Figure 2. No coinfection between Leishmania spp. and FeLV was found.

Several studies have reported Leishmania infection in cats in regions endemic for canine and human leishmaniasis (VIDES et al., 2011; SHERRY et al., 2011; CHATZIS et al., 2014; PENNISI et al., 2015; SPADA et al., 2016). In the present study, the occurrence of antibodies against Leishmania spp. was observed in $15.38 \%$ of the cats evaluated from Mossoró- a city endemic for this disease (AMÓRA et al., 2006; BARBOSA, 2013). To the best of our knowledge, this is the first study to report FeL in Rio Grande do Norte State.

The seropositivity here observed was lower than that found in a study with dogs from Mossoró. Using IFAT and ELISA, these authors found frequencies of Leishmania spp. seropositivity of $34 \%$ and $45 \%$ for dogs living in urban and rural zones, respectively (AMÓRA et al., 2006). The low number of cats seropositive for Leishmania spp. in comparison with dogs has been shown

Table 1. Clinical manifestations of domestic cats seropositive for Leishmania spp. on IFAT from Mossoró city ( $\mathrm{n}=14)$, Rio Grande do Norte state, Brazil.

\begin{tabular}{cccccl}
\hline Animal & Age (years) & Sex & IFAT titer & FIV-status & Clinical signs \\
\hline$\# 2$ & 7 & $\mathrm{~F}$ & $1: 80$ & $\mathrm{~N}$ & Asymptomatic \\
$\# 27$ & 10 & $\mathrm{M}$ & $1: 80$ & $\mathrm{P}$ & Gingivostomatitis \\
$\# 40$ & 12 & $\mathrm{M}$ & $1: 80$ & $\mathrm{P}$ & Bronchopneumonia, gingivostomatitis, lymphadenomegaly \\
$\# 43$ & 9 & $\mathrm{~F}$ & $1: 40$ & $\mathrm{P}$ & Squamous cell carcinoma in nasal and palpebral border, chronic rhinitis \\
$\# 48$ & 3 & $\mathrm{M}$ & $1: 40$ & $\mathrm{~N}$ & Bilateral blepharitis \\
$\# 51$ & 1 & $\mathrm{~F}$ & $1: 320$ & $\mathrm{~N}$ & Ulcerated plaque lesions with difficult healing, lymphadenomegaly \\
$\# 55$ & 2 & $\mathrm{M}$ & $1: 80$ & $\mathrm{~N}$ & Chronic kidney disease \\
$\# 56$ & 8 & $\mathrm{M}$ & $1: 160$ & $\mathrm{P}$ & Alopecia, erythema and desquamation in ear borders, chronic kidney disease \\
$\# 72$ & 3 & $\mathrm{M}$ & $1: 40$ & $\mathrm{~N}$ & Cutaneous abscess \\
$\# 73$ & 6 & $\mathrm{M}$ & $1: 40$ & $\mathrm{P}$ & Gingivostomatitis \\
$\# 80$ & 11 & $\mathrm{M}$ & $1: 80$ & $\mathrm{~N}$ & Bronchopneumonia \\
$\# 85$ & 3 & $\mathrm{~F}$ & $1: 40$ & $\mathrm{~N}$ & Asymptomatic \\
$\# 86$ & 9 & $\mathrm{~F}$ & $1: 40$ & $\mathrm{~N}$ & Asymptomatic \\
$\# 91$ & 10 & $\mathrm{~F}$ & $1: 40$ & $\mathrm{~N}$ & Asymptomatic \\
\hline
\end{tabular}

\# - number of the animal; F- female; $\mathrm{M}$ - male; N- negative; P- positive.

Table 2. Distribution of IFAT titers (IgG) for Leishmania spp. in domestic cats from Mossoró city, Rio Grande do Norte State, Brazil ( $\mathrm{n}=91)$.

\begin{tabular}{|c|c|c|c|}
\hline & Number of positive cats & Titer & $(\%)$ \\
\hline \multirow[t]{4}{*}{ Leishmania spp. } & 7 & $1: 40$ & 7.69 \\
\hline & 5 & $1: 80$ & 5.49 \\
\hline & 1 & $1: 160$ & 1.09 \\
\hline & 1 & $1: 320$ & 1.09 \\
\hline
\end{tabular}




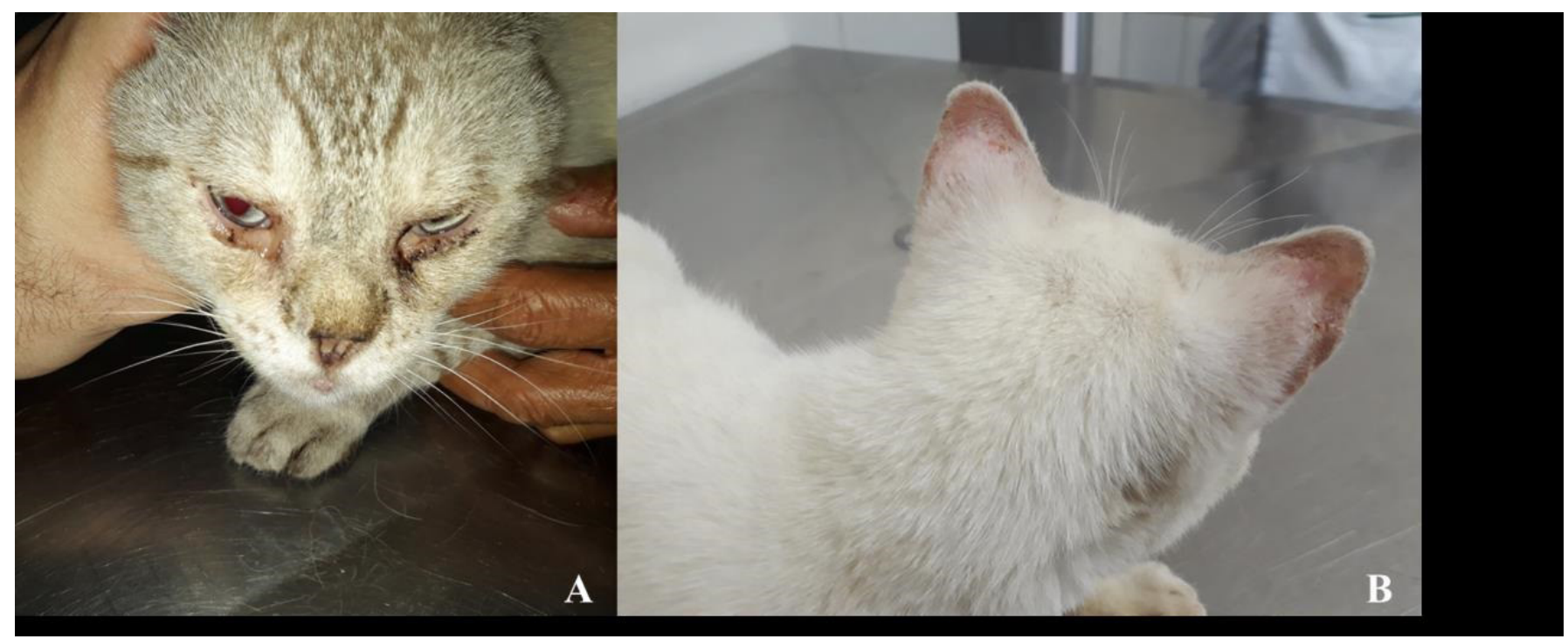

Figure 1. Clinical manifestations of Leishmania spp. seropositive cats from Mossoró city, Rio Grande do Norte State, Brazil. (A) Animal \#48 (Male, 3-year-old, FIV-negative, IFAT titer of 1:40) with bilateral blepharitis; (B) Animal \#56 (Male, 8-year-old, FIV-positive, IFAT titer of 1:160) with alopecia on ear borders associated with erythema and desquamation.

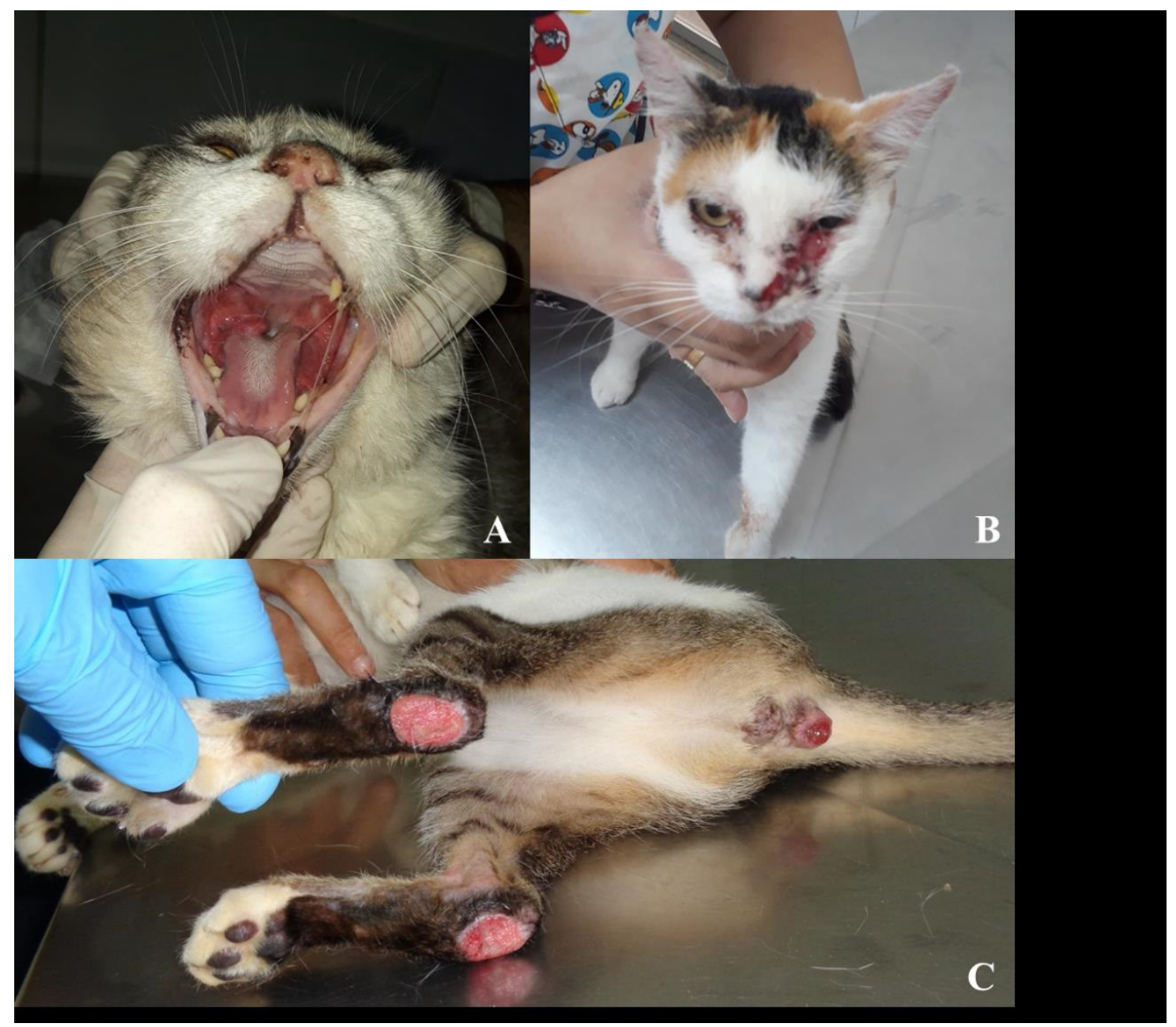

Figure 2. Clinical manifestations of Leishmania spp. seropositive cats from Mossoró city, Rio Grande do Norte State, Brazil. (A) Animal \#27 (Male, 10-year-old, FIV-positive, IFAT titer of 1:80) presenting chronic gingivostomatitis; (B) Animal \#43 (Female, 9-year-old, FIV-positive, IFAT titer of 1:40) with a squamous cell carcinoma ulcerative lesion involving nasal and palpebral borders; (C) Animal \#51 (Female, 1-year-old, FIV-negative, IFAT titer of 1:320). Ulcerative lesions in plaque located in calcaneal region, with 5 months of evolution time and difficult healing. 
by other research groups (SOLANO-GALLEGO et al., 2007; BRESCIANI et al., 2010; SOBRINHO et al., 2012; CARDIA et al., 2013), and this can be attributed to the natural resistance of the cats against the protozoan, due to a more effective cellular immune response (SOLANO-GALLEGO et al., 2007). Moreover, the use of different methodologies and non-standardized protocols could also be responsible for these frequencies (SOLANO-GALLEGO et al., 2011).

In dogs with leishmaniasis, coinfections with other pathogens such as Ehrlichia canis and Dirofilaria immitis can interfere with the parasite burden and affect disease progression because of the alterations in the immune response (TABAR at al., 2013; TOMMASI et al., 2013). In cats, the majority of leishmaniasis coinfections investigations are related to retroviruses, which cause immunosuppressive diseases (PENNISI \& PERSICHETTI, 2018). However, only a few studies have found a significant association between Leishmania spp. seropositivity and FIV (PENNISI et al., 1998; AYLLÓN et al., 2012; SOBRINHO et al., 2012; SPADA et al., 2013) and FeLV infection (SHERRY et al., 2011).

During the course of feline retroviral infections, there is progressive immunosuppression due to the changes in the CD4 and CD8 lymphocyte count, which predisposes the animal to a variety of opportunistic pathogens (LACERDA et al., 2017). In this context, FIV-positive cats can represent a risk to Leishmania spp. infection, as humans infected by the human immunodeficiency virus (HIV) are known to be predisposed to leishmaniasis (PAGLIANO \& ESPOSITO, 2017). In this study, in spite of the fact that no statistically significant association was found between FeL and FIV, five $(37.5 \%)$ of the 14 cats seropositive for leishmaniasis presented coinfection with FIV and showed clinical signs suggestive of FeL (PENNISI et al., 2015). Further case-control studies are needed to assess the dynamics of these two contagious diseases in the evaluated region.

Very few studies were performed to investigate FeL in Northeast Brazil. The FeL seropositivity here was higher than that observed in Recife and Teresina, where $3.9 \%$ and $4 \%$ of the cats were found be seropositive for FeL using ELISA (SILVA et al., 2014; MENDONÇA et al., 2017). Sero-epidemiological investigations in other regions of the country found frequencies varying from $0.5 \%$ to $54 \%$, using IFAT and the same cut-off value adopted here (1:40) (VIDES et al., 2011; CARDIA et al., 2013; BRAGA et al., 2014; SOUSA et al., 2014; OLIVEIRA et al., 2015; GODOI et al., 2016; COURA et al., 2018; MATOS et al., 2018). In canine leishmaniasis, high serological titers (four times the established cut-off value) with clinical signs compatible with leishmaniasis are diagnostic for the disease (SOLANO-GALLEGO et al., 2011). Combining this information with the results obtained in the present study, cats with IFAT titers equal to or above 1:160 could have the confirmation of FeL.

The serological methods used to diagnose FeL are still the main tools for epidemiological studies and for investigation of the infection because of the low costs, good sensibility, and ease of obtaining blood samples from animals (SILVEIRA et al., 2015). IFAT is the most widely used method and was implemented in this study. Nevertheless, ELISA seems to have higher sensitivity (SILVEIRA et al., 2011; COELHO et al., 2011). This difference between the sensitivity of the methods and frequency of positive animals can be explained by the lack of studies on the standardization of diagnosis methods, associated with the little understanding of FeL immunology and pathophysiology, making the identification of infected animals a challenge (SPADA et al., 2013; SILVEIRA et al., 2015).

The molecular study of Leishmania spp. using PCR from blood samples did not give positive results for any of the animals. Similar results were observed by other authors, i.e., seropositive cats testing negative on PCR (BRAGA et al., 2014; CHATZIS et al., 2014; NOÉ et al., 2015; MONTOYA et al., 2018; COURA et al., 2018). This finding could be explained by the capability of the protozoan to compartmentalize in determined lymphoid organs such as bone marrow, lymph nodes, and spleen, by the absence of parasitemia at the moment of the blood collection, or because of a parasite burden lower than that of the detection limit of the test used (CHATZIS et al., 2014; COURA et al., 2018). Another hypothesis for the presence of seropositive animals with negative PCR result could be related to the possibility of cross-reactions with antibodies against other parasites, especially other species of Leishmania and Trypanosoma (ZANETTE et al., 2014; SILVEIRA et al., 2015; SOARES et al., 2016).

In spite of no statistical association was found between presence of antibodies against Leishmania spp. and specific clinical signs assessed (cutaneous signs, lymphadenomegaly, ophthalmic signs, gingivostomatitis, weight loss, and pale mucosa), the majority of cats seropositive for Leishmania spp. in this study presented clinical signs that associated with FeL (PENNISI et al., 2015; PENNISI \& PERSICHETTI, 2018). Another important finding was a concurrent squamous cell carcinoma in a seropositive feline. Some studies have suggested a synergism between FeL and this neoplasia (GREVOT et al., 2005; POCHOLLE et al., 2012; MAIA et al., 2015; SOARES et al., 2016). It is important to emphasize that serological evidence and clinical signs of Leishmania spp. infection were found in this study, although infection was not reinforced by PCR.

The evidences are still insufficient to determine the real role of the cats in the epidemiological chain of leishmaniasis transmission (PENNISI \& PERSICHETTI, 2018). It is believed that cats can act as a secondary reservoir for Leishmania spp. Under natural conditions, however, in the absence of the primary reservoir, cats alone would not be capable of transmitting the infection to sand flies (PENNISI et al., 2015). However, it has been suggested that hares and not dogs served as reservoirs of leishmaniasis during an outbreak of human leishmaniasis in Spain (MOLINA et al., 2012; MORENO et al., 2014). Therefore, as the population of domestic and stray cats is bigger than the dog population in some endemic areas, cats could have an important role in leishmaniasis transmission in these locations (PENNISI et al., 2015).

The presence of antibodies against Leishmania spp. suggests that these animals are being exposed to and may be infected by this protozoan. The cats might represent an important link in the epidemiological chain of leishmaniasis transmission in the studied region. As this disease has a great impact on public health, further studies should be performed to investigate the clinical, pathophysiological, and epidemiological aspects of this infection in domestic cats. 


\section{Acknowledgements}

We would like to thank the Coordenaçáo de Aperfeiçoamento de Pessoal de Nível Superior - Brasil (CAPES) to support the scholarship of JABB.

\section{References}

Akhtardanesh B, Kheirandish R, Sharifi I, Mohammadi A, Mostafavi A, Mahmoodi T, et al. Low susceptibility of domestic cats to experimental Leishmania infantum infection. J Vector Borne Dis 2018; 55(3): 230-234. http://dx.doi.org/10.4103/0972-9062.249481. PMid:30618450.

Amóra SSA, Santos MJP, Alves ND, Costa SCG, Calabrese KS, Monteiro AJ, et al. Fatores relacionados com a positividade de cães para leishmaniose visceral em área endêmica do Estado do Rio Grande do Norte, Brasil. Cienc Rural 2006; 36(6): 1854-1859. http://dx.doi.org/10.1590/S010384782006000600029 .

Ayllón T, Diniz PP, Breitschwerdt EB, Villaescusa A, Rodríguez-Franco F, Sainz A. Vector-borne diseases in client-owned and stray cats from Madrid, Spain. Vector Borne Zoonotic Dis 2012; 12(2): 143-150. http:// dx.doi.org/10.1089/vbz.2011.0729. PMid:22022820.

Barbosa IR. Epidemiologia da leishmaniose visceral no estado do Rio Grande do Norte, Brasil. Rev Epidemiol Control Infect 2013; 3(1): 17-21. http://dx.doi.org/10.17058/reci.v3i1.3148.

Braga AR, Corrêa AP, Camossi LG, Silva RC, Langoni H, Lucheis SB. Coinfection by Toxoplasma gondii and Leishmania spp. in domestic cats (Felis catus) in State of Mato Grosso do Sul. Rev Soc Bras Med Trop 2014; 47(6): 796-797. http://dx.doi.org/10.1590/0037-8682-0041-2014. PMid:25626663.

Bresciani KD, Serrano AC, Matos LV, Savani ES, D'Auria SR, Perri $\mathrm{SH}$, et al. Ocorrência de Leishmania spp. em felinos do município de Araçatuba, SP. Rev Bras Parasitol Vet 2010; 19(2): 127-129. http://dx.doi. org/10.1590/S1984-29612010000200012. PMid:20624352.

Camargo ME. Introdução às técnicas de imunofluorescência. Rev Bras Patol Clin 1974; 10(1): 143-169.

Cardia DF, Camossi LG, Silveira L No, Langoni H, Bresciani KD. Prevalence of Toxoplasma gondii and Leishmania spp. Infection in cats from Brazil. Vet Parasitol 2013; 197(3-4): 634-637. http://dx.doi. org/10.1016/j.vetpar.2013.07.017. PMid:23932640.

Chatzis MK, Andreadou M, Leontides L, Kasabalis D, Mylonakis M, Koutinas AF, et al. Cytological and molecular detection of Leishmania infantum in different tissues of clinically normal and sick cats. Vet Parasitol 2014; 202(3-4): 217-225. http://dx.doi.org/10.1016/j.vetpar.2014.02.044. PMid:24629427.

Coelho WM, Amarante AF, Apolinário JC, Coelho NM, Lima VM, Perri $\mathrm{SH}$, et al. Seroepidemiology of Toxoplasma gondii, Neospora caninum, and Leishmania spp. infections and risk factors for cats from Brazil. Parasitol Res 2011; 109(4): 1009-1013. http://dx.doi.org/10.1007/s00436-0112461-x. PMid:21626423.

Coura FM, Passos SKP, Pelegrino MOF, Leme FOP, Paz GF, Gontijo CMF, et al. Serological, molecular, and microscopic detection of Leishmania in cats (Felis catus) in Belo Horizonte, Minas Gerais State, Brazil. Rev Bras Parasitol Vet 2018; 27(4): 570-574. http://dx.doi.org/10.1590/ s1984-296120180052. PMid:30183999.
Godoi NFC, Bittencourt LHFB, Andrade ACS, Picolotto GCGP, Marchan PRAC. Prevalência de anticorpos anti-Leishmania infantum em felinos domésticos frequentadores de clínicas e hospitais veterinários da cidade de Cascavel, Paraná, Brasil. Arq Ciênc Vet Zool UNIPAR 2016; 19(1): 11-16. http://dx.doi.org/10.25110/arqvet.v19i1.2016.5785.

Grevot A, Jaussaud Hugues P, Marty P, Pratlong F, Ozon C, Haas P, et al. Leishmaniosis due to Leishmania infantum in a FIV and FeLV positive cat with a squamous cell carcinoma diagnosed with histological, serological and isoenzymatic methods. Parasite 2005; 12(3): 271-275. http://dx.doi. org/10.1051/parasite/2005123271. PMid:16218216.

Lacerda LC, Silva AN, Freitas JS, Cruz RDS, Said RA, Munhoz AD. Feline immunodeficiency virus and feline leukemia virus: frequency and associated factors in cats in northeastern Brazil. Genet Mol Res 2017; 16(2): gmr16029633. http://dx.doi.org/10.4238/gmr16029633. PMid:28510253.

Maia C, Sousa C, Ramos C, Cristóvão JM, Faísca P, Campino L. First case of feline leishmaniosis caused by Leishmania infantum genotype $\mathrm{E}$ in a cat with a concurrent nasal squamous cell carcinoma. JFMS Open Rep 2015; 1(2): 1-5. https://dx.doi.org/10.1177\%2F2055116915593969.

Maia-Elkhoury ANS, Alves WA, Sousa-Gomes ML, Sena JM, Luna EA. Visceral Leishmaniasis in Brazil: trends and challenges. Cad Saude Publica 2008; 24(12): 2941-2947. http://dx.doi.org/10.1590/S0102311X2008001200024. PMid:19082286.

Maroli M, Pennisi MG, Di Muccio T, Khoury C, Gradoni L, Gramiccia M. Infection of sandflies by a cat naturally infected with Leishmania infantum. Vet Parasitol 2007; 145(3-4): 357-360. http://dx.doi.org/10.1016/j. vetpar.2006.11.009. PMid:17174035.

Matos AMRN, Caldart ET, Ferreira FP, Monteiro KC, Souza M, Brunieri DTSC, et al. Antibodies anti-trypanosomatides in domestic cats in Paraná: who is at highest risk of infection? Rev Bras Parasitol Vet 2018; 27(2): 232236. http://dx.doi.org/10.1590/s1984-296120180033. PMid:29846450.

Mendonça IL, Batista JF, Ribeiro IMM, Rocha FSB, Silva SO, Melo MN. Leishmania infantum in domestic cats from the municipality of Teresina, state of Piauí, Brazil. Parasitol Open 2017; 3(1): e1. http:// dx.doi.org/10.1017/pao.2017.1.

Molina R, Jiménez M, Cruz I, Iriso A, Martín-Martín I, Sevillano O, et al. The hare (Lepus granatensis) as potential sylvatic reservoir of Leishmania infantum in Spain. Vet Parasitol 2012; 190(1-2): 268-271. http://dx.doi. org/10.1016/j.vetpar.2012.05.006. PMid:22677135.

Montoya A, García M, Gálvez R, Checa R, Marino V, Sarquis J, et al. Implications of zoonotic and vector-borne parasites to free-roaming cats in central Spain. Vet Parasitol 2018; 251: 125-130. http://dx.doi. org/10.1016/j.vetpar.2018.01.009. PMid:29426469.

Moreno I, Álvarez J, García N, De La Fuente S, Martínez I, Mariño E, et al. Detection of anti-Leishmania infantum antibodies in sylvatic lagomorphs from an epidemic area of Madrid using the indirect immunofluorescence antibody test. Vet Parasitol 2014; 199(3-4): 264-267. http://dx.doi. org/10.1016/j.vetpar.2013.10.010. PMid:24211046.

Noé P, Domingos SL, Oshiro ET, Lima RB, Pirmez C, Pedroso TC, et al. Detection of Leishmania chagasi in cats (Felis catus) from viscera leishmaniasis endemic area in Brazil. Ciênc Anim 2015; 25(4): 3-14.

Oliveira GC, Paiz LM, Menozzi BD, Lima MS, Moraes CC, Langoni H. Antibodies to Leishmania spp. in domestic felines. Rev Bras Parasitol Vet 2015; 24(4): 464-470. http://dx.doi.org/10.1590/S1984-29612015071. PMid:26689182. 
Pagliano P, Esposito S. Visceral leishmaniosis in immunocompromised host: an update and literature review. J Chemother 2017; 29(5): 261-266. http://dx.doi.org/10.1080/1120009X.2017.1323150. PMid:28490252.

Pennisi MG, Cardoso L, Baneth G, Bourdeau P, Koutinas A, Miró $\mathrm{G}$, et al. LeishVet update and recommendations on feline leishmaniosis. Parasit Vectors 2015; 8(1): 302. http://dx.doi.org/10.1186/s13071-0150909-z. PMid:26041555.

Pennisi MG, Masucci M, Catarsini O. Presenza di anticorpi antiLeishmania in gatti FIV+ che vivono in zona endemica. Atti Soc Ital Sci Vet 1998; 52: 265-266

Pennisi MG, Persichetti MF. Feline leishmaniosis: is the cat a small dog? Vet Parasitol 2018; 251: 131-137. http://dx.doi.org/10.1016/j. vetpar.2018.01.012. PMid:29426470.

Pocholle E, Reyes-Gomez E, Giacomo A, Delaunay P, Hasseine L, Marty P. Un cas de leishmaniose féline disséminée dans le sud de la France. Parasite 2012; 19(1): 77-80. http://dx.doi.org/10.1051/parasite/2012191077. PMid:22314243.

Sherry K, Miró G, Trotta M, Miranda C, Montoya A, Espinosa C, et al. A serological and molecular study of Leishmania infantum infection in cats from the Island of Ibiza (Spain). Vector Borne Zoonotic Dis 2011; 11(3): 239-245. http://dx.doi.org/10.1089/vbz.2009.0251. PMid:20804432.

Silva RC, Ramos RA, Pimentel DS, Oliveira GM, Carvalho GA, Santana MA, et al. Detection of antibodies against Leishmania infantum in cats (Felis catus) from the state of Pernambuco, Brazil. Rev Soc Bras Med Trop 2014; 47(1): 108-109. http://dx.doi.org/10.1590/0037-8682-00052012. PMid:24603746.

Silva SM, Rabelo PF, Gontijo NF, Ribeiro RR, Melo MN, Ribeiro VM, et al. First report of infection of Lutzomyia longipalpis by Leishmania (Leishmania) infantum from a naturally infected cat of Brazil. Vet Parasitol 2010; 174(1-2): 150-154. http://dx.doi.org/10.1016/j.vetpar.2010.08.005. PMid:20832944.

Silveira L No, Marcondes M, Bilsland E, Matos LVS, Viol MA, Bresciani KDS. Clinical and epidemiological aspects of feline leishmaniasis in Brazil. Semina: Ciênc Agrár 2015; 36(3): 1467-1480. http://dx.doi. org/10.5433/1679-0359.2015v36n3p1467.

Silveira L No, Sobrinho LS, Martins CO, Machado RZ, Marcondes M, Lima VM. Use of crude, FML and rK39 antigens in ELISA to detect anti-Leishmania spp. antibodies in Felis catus. Vet Parasitol 2011; 177(3-4): 374-377. http://dx.doi.org/10.1016/j.vetpar.2010.11.055. PMid:21195550.

Soares CS, Duarte SC, Sousa SR. What do we know about feline leishmaniosis? J Feline Med Surg 2016; 18(6): 435-442. http://dx.doi. org/10.1177/1098612X15589358. PMid:26116620.

Sobrinho LS, Rossi CN, Vides JP, Braga ET, Gomes AA, Lima VM, et al. Coinfection of Leishmania chagasi with Toxoplasma gondii, Feline Immunodeficiency Virus (FIV) and Feline Leukemia Virus (FeLV) in cats from an endemic area of zoonotic visceral leishmaniasis. Vet Parasitol
2012; 187(1-2):302-306. http://dx.doi.org/10.1016/j.vetpar.2012.01.010 PMid:22285010.

Solano-Gallego L, Iniesta L, Rodríguez-Cortés A, Pastor J, Quintana J, Espada Y, et al. Cross-sectional serosurvey of feline leishmaniasis in ecoregions around the Northwestern Mediterranean. Am J Trop Med Hyg 2007; 76(4): 676-680. http://dx.doi.org/10.4269/ajtmh.2007.76.676. PMid:17426169.

Solano-Gallego L, Miró G, Koutinas A, Cardoso L, Pennisi MG, Ferrer $\mathrm{L}$, et al. LeishVet guidelines for the practical management of canine leishmaniosis. Parasit Vectors 2011; 4(1): 86. http://dx.doi.org/10.1186/17563305-4-86. PMid:21599936.

Sousa KC, Herrera HM, Domingos IH, Campos JB, Santos IM, Neves $\mathrm{HH}$, et al. Serological detection of Toxoplasma gondii, Leishmania infantum and Neospora caninum in cats from an area endemic for leishmaniasis in Brazil. Rev Bras Parasitol Vet 2014; 23(4): 449-455. http://dx.doi. org/10.1590/s1984-29612014078. PMid:25517522.

Spada E, Canzi I, Baggiani L, Perego R, Vitale F, Migliazzo A, et al. Prevalence of Leishmania infantum and co-infections in stray cats in northern Italy. Comp Immunol Microbiol Infect Dis 2016; 45: 53-58. http://dx.doi.org/10.1016/j.cimid.2016.03.001. PMid:27012922.

Spada E, Proverbio D, Migliazzo A, Della Pepa A, Perego R, Bagnagatti De Giorgi G. Serological and molecular evaluation of Leishmania infantum infection in stray cats in a nonendemic area in Northern Italy. ISRN Parasitol 2013; 916376: 916376. http://dx.doi.org/10.5402/2013/916376. PMid:27335864.

Tabar MD, Altet L, Martínez V, Roura X. Wolbachia, filariae and Leishmania coinfection in dogs from a Mediterranean area.J Small Anim Pract 2013 54(4): 174-178. http://dx.doi.org/10.1111/jsap.12041. PMid:23425244.

Tommasi AS, Otranto D, Dantas-Torres F, Capelli G, Breitschwerdt EB, Caprariis D. Are vector-borne pathogen co-infections complicating the clinical presentation in dogs? Parasit Vectors 2013; 6(1): 97. http:// dx.doi.org/10.1186/1756-3305-6-97. PMid:23587324.

Vides JP, Schwardt TF, Sobrinho LS, Marinho M, Laurenti MD, Biondo AW, et al. Leishmania chagasi infection in cats with dermatologic lesions from an endemic area of visceral leishmaniosis in Brazil. Vet Parasitol 2011; 178(1-2): 22-28. http://dx.doi.org/10.1016/j.vetpar.2010.12.042. PMid:21282011.

Volpini AC, Passos VM, Oliveira GC, Romanha AJ. PCR-RFLP to identify Leishmania (Viannia) braziliensis and L. (Leishmania) amazonensis causing American cutaneous leishmaniasis. Acta Trop 2004; 90(1): 31-37. http://dx.doi.org/10.1016/j.actatropica.2003.10.008. PMid:14739020.

Zanette MF, Lima VM, Laurenti MD, Rossi CN, Vides JP, Vieira RF, et al. Serological cross-reactivity of Trypanosoma cruzi, Ehrlichia canis, Toxoplasma gondii, Neospora caninum and Babesia canis to Leishmania infantum chagasi tests in dogs. Rev Soc Bras Med Trop 2014; 47(1): 105-107. http://dx.doi. org/10.1590/0037-8682-1723-2013. PMid:24603745. 